\title{
Incidence of malignant mixed ovarian germ cell tumours in a tertiary care hospital: A five year retrospective study
}

Emilio M Treviño-Salinas ${ }^{*}$, Karen A Pinto-García ${ }^{1}$, José G Garza-Leal ${ }^{1}$, Oralia Barboza-Ouintana ${ }^{2}$, Gabriela García-Tamez ${ }^{1}$, Mauricio Delgado-Morquecho ${ }^{2}$ and Américo Guadalupe Alvarado Valadez ${ }^{1}$

${ }^{1}$ Department of Gynecology and Obstetrics, University Hospital “Dr. José Eleuterio González” UANL

${ }^{2}$ Department of Anatomical Pathology and Cytopathology, University Hospital “Dr. José Eleuterio González” UANL

\begin{abstract}
Malignant mixed ovarian germ cell tumours, typically present in the teenage years, are a rare group of rapidly growing and highly aggressive neoplasms that are derived from the primitive germ cells of the embryonal gonad representing $5 \%$ of all malignant ovarian germ cell tumours. The objective of this study was to analyze the incidence of these tumours in our reference hospital and compare the results with those reported in the literature. We analyzed all cases of ovarian tumours during the period from January 2015 to December 2019 and malignant mixed germ cell tumours were selected for analysis. Only 5 cases (9.2\%) were histologically diagnosed among 1080 patients with ovarian cancer diagnosis; the mean age of presentation was 17.4 years, abdominal pain was the most common symptom, fertility preservation surgery was practiced in the majority of cases $(n=3 / 5)$. According to our findings, the incidence rates, surgical approach and chemotherapy responds are very similar to the rates reported in the Western literature.
\end{abstract}

\section{Introduction}

Ovarian germ cell tumours originate from primitive germ cells of the embryonic gonad ovary and are rapidly growing heterogeneous neoplasms; malignant ovarian germ cell tumours (MOGCTs) are rare and highly aggressive neoplasms, comprising $<5 \%(\sim 2.6 \%)$ of all ovarian malignancies with higher incidence rates in Asian and Hispanic women.

Classification of malignant ovarian cell tumours in order of frequency include: dysgerminomas, immature teratomas, yolk sac tumours and mixed germ cell tumours; less common tumours include choriocarcinoma and embryonal carcinomas which are extremely rare and are more commonly part of mixed germ cell tumours. The diagnosis is usually suspected for the clinical presentation of a voluminous pelvic mass and abdominal discomfort but surgical intervention and histopathological study establishes the diagnosis.

The serum tumor markers alphafetoprotein, beta-human chorionic gonadotropin, lactic dehydrogenase and placental alkaline phosphatase are generally helpful in the diagnosis, management and surveillance of these tumors. Usually diagnosed in children and young women; are mainly unilateral and chemosensitive so the preservation of fertility and ovarian function is established as standard of care with the exception of those patients with advance disease who undergo cytoreductive surgery. Based on tumour stage and histological type, some of the patients receive chemotherapy after surgery.

The chemotherapy usually can be started one week after surgery; the BEP (Bleomycin, etoposide and cisplatin) regimen has shown to be effective and less toxic compared with other therapeutic regimens. The survival rate in patients diagnosed at early stages approach $100 \%$ by the combination of surgery and chemotherapy and almost a $75 \%$ in patients with advance stage disease.
The aim of this study is to establish the incidence of malignant mixed germ cell tumours among our population and our experience in the management of this group of rare ovarian tumours.

\section{Material and methods}

We conducted a retrospective longitudinal study from January 2015 to December 2019. All the patients with ovarian cancer treated in the Department of Obstetrics and Gynecology, University Hospital "Dr. José Eleuterio González" were studied. From the data bank of the Department of Pathology a total of 54 patients among 1080 patients with ovarian cancer were diagnosed with malignant ovarian germ cell tumour. Only five patients had the histological diagnosis of malignant mixed germ cell tumours.

We analyzed the age, clinical presentation, histological type, preoperative and post-treatment serum tumor markers levels, affected side, surgical procedure, surgical staging findings; the chemotherapy used was also assessed.

\section{Results}

The incidence of MOGCTs was 5\% $(n=54 / 1080)$. Malignant mixed germ cell tumour specifically accounted for $9.2 \%(n=5 / 54)$ all of them confirmed by the pathologist at the University Hospital "Dr. José Eleuterio González".

${ }^{\star}$ Correspondence to: Emilio M Treviño-Salinas. Departamento de Ginecología y Obstetricia del Hospital Universitario “Dr. José Eleuterio González”. Av. Madero y Gonzalitos sin número Col. Mitras Centro CP 64460 Monterrey Nuevo León México, E-mail: trevinoemilio@yahoo.com.mx

Key words: mixed ovarian germ cell tumor, ovarian cancer

Received: May 13, 2020; Accepted: May 29, 2020; Published: June 05, 2020 
The mean age of the patients was 17.4 years with a range of $9-26$ years; three patients were under 17 years.

The principal clinical presentation was abdominal pain in $60 \%$ $(n=3)$ of the patients; ascites was present in $80 \%(n=4)$ of the patients at the moment of diagnosis. One case was reported as a finding during C-section.

Unilateral oophorectomy was performed for 3 patients (60\%); the right ovary was affected in two patients and the left ovary in one. Hysterectomy with left salpingo-oophorectomy was performed in one patient; one patient underwent hysterectomy with bilateral salpingooophorectomy. Omentectomy and pelvic lymph node dissection was performed in 2 patients.

The serum tumour markers analyzed are described in Table 1; they were measured at the moment of diagnosis and after treatment. The only two serum markers used were Alpha-fetoprotein and B-hGC, both had a significant descend after treatment.

The majority of patients were Stage IVB (60\%). One patient (20\%) was Stage IIIC and one (20\%) was Stage IA.

The germ cell components of the tumours are summarized in Table 2. We had two cases $(40 \%)$ of tumors composed of the combination of three germ cell components. The remaining three cases $(60 \%)$ were composed for two components.

All of our five patients received the BEP regimen after surgical treatment; three $(80 \%)$ of them for four cycles, one (10\%) for 3 cycles and the other one (10\%) for 6 cycles (Table 3 ). Currently four patients are on cancer surveillance with negative serum tumour markers free of disease, one of them got pregnant after her chemotherapy regimen; only one death was reported at the time of the study.

\section{Discussion}

In our study the incidence of malignant ovarian germ cell tumours (5\%) was similar to the incidence reported in the United States and Western populations (3\%). Mixed malignant ovarian germ cell tumours incidence reported worldwide (10\%) is very similar to the incidence found in our study $(9.2 \%)$ [1-3].

Table 1. Preoperative and post-treatment serum tumour levels

\begin{tabular}{|c|c|c|c|c|}
\hline \multicolumn{5}{|c|}{ Preoperative and Post-treatment Serum Tumour Levels } \\
\hline Patient & $\begin{array}{c}\text { PO Alpha- } \\
\text { fetoprotein } \\
(\mathrm{ng} / \mathrm{mL})\end{array}$ & $\begin{array}{c}\text { PT Alpha- } \\
\text { fetoprotein } \\
(\mathrm{ng} / \mathrm{mL})\end{array}$ & $\begin{array}{c}\text { PO B-hCG } \\
(\mathrm{mUI} / \mathrm{mL})\end{array}$ & $\begin{array}{c}\text { PT B-hCG } \\
(\mathrm{mUI} / \mathrm{mL})\end{array}$ \\
\hline 1 & 42.9 & $<0.6$ & 5787 & $<0.1$ \\
\hline 2 & 1210 & 7.5 & 0.67 & 0.45 \\
\hline 3 & 284 & 2.9 & 1.0 & 0.26 \\
\hline 4 & 537 & 3.8 & 1.66 & 0.15 \\
\hline 5 & $>1210$ & 1.72 & 148 & 8.34 \\
\hline
\end{tabular}

PO: Preoperative, PT: Post-treatment, B-hCG: beta human chorionic gonadotropin.

Table 2. Germ cell components of the tumours

\begin{tabular}{|c|c|c|c|c|c|}
\hline \multicolumn{7}{|c|}{ Germ cell components of the tumours } \\
\hline Patient & Dysgerminoma & $\begin{array}{l}\text { Endodermal } \\
\text { Sinus tumor }\end{array}$ & $\begin{array}{c}\text { Immature } \\
\text { Teratoma }\end{array}$ & $\begin{array}{c}\text { Embryonal } \\
\text { Carcinoma }\end{array}$ & Choriocarcinoma \\
\hline 1 & - & - & $50 \%$ & $30 \%$ & $20 \%$ \\
\hline 2 & $40 \%$ & $60 \%$ & - & - & - \\
\hline 3 & $50 \%$ & - & - & $50 \%$ & - \\
\hline 4 & - & $30 \%$ & $70 \%$ & - & - \\
\hline 5 & $5 \%$ & $80 \%$ & - & $15 \%$ & - \\
\hline
\end{tabular}

Table 3. Summary of patients with mixed malignant ovarian germ cell tumours Summary of Patients with Mixed Malignant Ovarian Germ Cell Tumours.

\begin{tabular}{|c|c|c|c|c|c|c|}
\hline Patient & Age & Surgery & Stage & Histology & Chemotherapy & Current status \\
\hline 1 & 9 & RO & IVB & IT-EC-ChC & BEP & NED \\
\hline 2 & 18 & LO & IVB & Dysg-EST & BEP & DOD \\
\hline 3 & 17 & RO & IA & Dysg-EC & BEP & NED \\
\hline 4 & 26 & AH-LSO & IIIC & EST-IT & BEP & NED \\
\hline 5 & 17 & AH-BSO & IVB & Dysg-EST-EC & BEP & NED \\
\hline
\end{tabular}

RO: Right oophorectomy, LO: Left oophorectomy, AH: Abdominal hysterectomy, LSO: Left salpingo-oophorectomy, BSO: Bilateral salpingo-oophorectomy, IT: Immature teratoma, EC: Embryonal carcinoma, ChC: Choriocarcinoma, Dysg: Dysgerminoma, EST: Endodermal sinus tumour, BEP: Bleomycin, etoposide and cisplatin, NED: No evidence of disease, DOD: Died of disease.

Ovarian mixed malignant germ cell tumors contain two or more types of germ cell combined. The majority of ovarian mMOGCT show a combination of two germ cell components; the most common components documented are dysgerminoma with yolk sac tumor (YST) followed by YST and immature teratoma [4]. It is also reported tumors showing combinations of three germ cell components with an incidence of $14-31 \%$ and 2 to $10 \%$ for those composed of four germ cell components [5-10]. Our incidence of tumors composed of three components was $40 \%$ of the cases, very similar to those reported in the literature. According to the Western literature, the mean age at the time of diagnosis is 18 years which coincide with the mean age ( 17.4 years) found in our study.

Abdominal pain was the commonest presenting symptom in our patients, as is reported in other studies [11]. As malignant mixed ovarian germ cell tumors are more common among young women, the conservation of the reproductive function is vital within these patients. It has been reported the safety of unilateral oophorectomy in the treatment of these tumors on early stages achieving a high rate of survival. In our study, two among the three patients who underwent conservative surgery are now free of disease and one of them was pregnant during the data recompilation.

All five patients were treated with Bleomycin, Etoposide and Cisplatinum chemotherapy. As reported in the literature, chemotherapy response was excellent with the BEP regimen; four patients were disease free and only one patient went under a new chemotherapy regimen (Paclitaxel, Ifosfamide and Cisplatin) [6,8]. As is documented in the literature, mixed malignant ovarian germ cell tumours are a very rare group of neoplasm in our population; according to our findings, the incidence rates, surgical approach and chemotherapy responds are very similar to the rates reported in the Western literature.

The experiences reported from different institutions keep contributing to the optimal management of this rare and aggressive group of tumours.

\section{Conflicts of interest}

The authors declare no conflicts of interest.

\section{Acknowledgments}

We thank for Patricia Gutierrez her assistance in data collection.

\section{References}

1. Smith HO, Berwick M, Verschraegen CF (2006) Incidence and survival rates for female malignant germ cell tumors. Obstet Gynecol 107: 1075-1085.

2. Bidus MA, Elkas JC, Rose GS. Germ cell, stromal, and other ovarian tumors. In; DiSaia PJ, Creasman WT, Mannel RS, McMeekin DS, Mutch DG, editors. Clinical Gynecologic Oncology. New York; Elsevier; 2012: 290. E731.e7 
3. Gershenson DM (2007) Management of ovarian germ cell tumors. J Clin Oncol 25 2938-2943

4. Koshy M, Vijayananthan A, Vadiveloo V (2005) Malignant ovarian mixed germ cell tumour: a rare combination. Biomed Imaging Interv $J$ 1: e10

5. Chen VW, Ruiz B, Killen JL, Coté TR, Wu XC, et al. (2003) Pathology and classification of ovarian tumors. Cancer $97: 2631-2642$

6. Sears S, Singh S, Shojaei H, Redline R, Resnick K (2017) High-dose chemotherapy and stem-cell rescue for salvage therapy for relapse malignant mixed ovarian germ cell tumor: A case report. Gynecol Oncol Rep 22: 72-74. [Crossref]

7. Ray-Coquard I. Ovarian tumors of sex cord-stromal origin. Orphanet Encyclopedia. March 2004.
8. Kim JH, Park JY, Kim JH, Kim YM, Kim YT, et al. (2018) The role of preoperative serum cancer antigen 125 in malignant ovarian germ cell tumors. Taiwan J Obstet Gynecol 57: 236-240. [Crossref]

9. C Newton, K Murali, A Ahmad, H Hockings, R Graham, et al. (2019) A multicenter retrospective cohort study of ovarian germ cell tumours: Evidence for chemotherapy de-escalation and alignment of pediatric and adult practice. Eur J Cancer 113: 19-27. [Crossref]

10. Li J, Wu X Current strategy for the treatment of ovarian germ cell tumors: role of extensive surgery. Curr Treat Options in Oncol 17: 44. [Crossref]

11. F K Lim, B Chanrachakul, S M Chong, S S Ratnam (1998) Malignant ovarian germ cell tumours: Experience in the National University Hospital of Singapore. Ann Acad Med Singapore 27: 657-661.

Copyright: (C2020 Treviño-Salinas EM. This is an open-access article distributed under the terms of the Creative Commons Attribution License, which permits unrestricted use, distribution, and reproduction in any medium, provided the original author and source are credited. 